\title{
PROJETO E ANÁLISE PRELIMINAR DE DESEMPENHO DE MOLDES POLIMÉRICOS NÃO ADESIVOS OBTIDOS POR IMPRESSÃO 3D VISANDO A OBTENÇÃO DE ESFEROIDES TECIDUAIS PARA A CONSTITUIÇÃO DE ESTRUTURAS CONDRAIS
}

\author{
Katlyn D. da Silva*, Monize C. Decarli, Jorge V. L. Silva, Ângela M. Moraes.
}

\begin{abstract}
Resumo
Os esferoides apresentam-se como uma das abordagens mais versáteis para obtenção de microtecidos in vitro, podendo, inclusive constituir as unidades construtoras do tecido em si. Este estudo teve como objetivo o levantamento de informações, por meio de extenso levantamento bibliográfico, acerca de aspectos relevantes na confecção e análise de desempenho de moldes poliméricos não adesivos obtidos por impressão 3D. Tais moldes se destinam à obtenção de esferoides teciduais e de seu uso, particularmente neste trabalho, na produção de estruturas úteis para a terapia de lesões de tecidos cartilaginosos. A técnica para a produção dos esferoides escolhida e estudada, denominada "Micromolded Nonadhesive Hydrogels Method", mostra-se como a mais eficiente e produtiva para esta finalidade. Como o projeto em si dos moldes micro-moldados envolve o uso de softwares de design assistido por computador (CAD) e é articulado à impressão 3D, também foram investigados os polímeros apropriados tanto para a obtenção dos micromoldes como da matriz para obtê-los. A matriz pode ser produzida com sucesso com poli(lactídeo-cocaprolactona), PLCL, policaprolactona, PCL, e poli(ácido lático), PLA, puros ou híbridos com polímeros naturais, como agarose e fibrina. Os micromoldes podem ser produzidos com polidimetilsiloxano (PDMS), poliuretanas, poliiminas ou Teflon $^{\mathrm{TM}}$. Os contramoldes podem ser obtidos em agarose, PDMS e ácido hialurônico.
\end{abstract}

\section{Palavras-chave:}

Scaffolds, biofabricação, estruturas condrais.

\section{Introdução}

Células animais cultivadas em 3D, como os esferoides, enquadram-se como mais próximas da arquitetura e das funções de um tecido nativo do que células cultivadas em 2D. Esferoides podem ser usados para se obter microtecidos in vitro. Nesse contexto, insere-se a Engenharia Tecidual, que visa projetar e confeccionar tecidos e órgãos funcionais para regenerar, reparar e repor tecidos lesados ou não funcionais. Para tal, devese controlar e escalonar técnicas reprodutíveis para a produção destas estruturas. Isto pode ser obtido pelo projeto de dispositivos moldados nos quais seja possível cultivar os esferoides. Por meio da impressão 3D podese confeccionar os moldes e usá-los, por exemplo, para obter esferoides de tamanho adequado para a terapia de lesões de tecidos cartilaginosos (Figura 1).

Figura 1. Projeto e confecção de moldes e obtenção de esferoides através do cultivo celular em micromoldes obtidos por impressão (Adaptada de Dernowsek, J, A. et al., 2016).

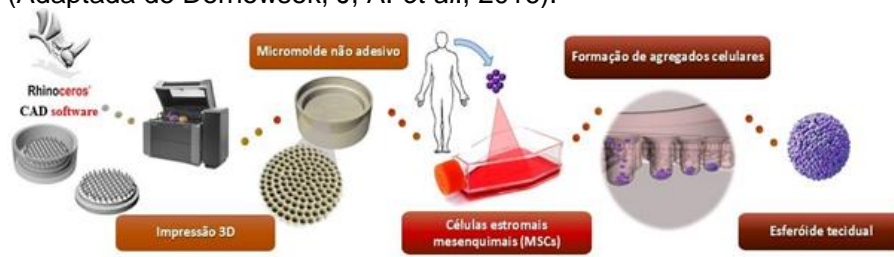

Resultados e Discussão

O projeto dos moldes pode ser desenvolvido em softwares CAD e articulado à impressão 3D por deposição do material camada a camada. Para os micromoldes, o polímero deve ser inerte, ter alta permeabilidade, transparência óptica e flexibilidade. Dentre estes, destacam-se o polidimetilsiloxano², PDMS, poliuretanos, poliiminas ou Teflon $^{\mathrm{TM}}$. No Centro de Tecnologia da Informação (CTI) Renato Archer, por exemplo, pode-se obter tais dispositivos utilizando-se a impressora Connex 350, com tecnologia Objet (Stratasys) em VeroClear (Figura 2). Obtido 0 micromolde, nele é colocado um hidrogel como o de agarose $^{3}$ ou fibrina 4 , para se obter um "contramolde" no qual são depositadas as células para a formação dos esferoides (Figura 1). Em seguida, deposita-se os esferoides em suportes biodegradáveis e biocompatíveis (macromoldes), também obtidos por impressão 3D. Nestes, esferoides vizinhos fundem-se para formar um tecido coeso. PLCL e PCL apresentam bons resultados com fibrina e agarose, respectivamente, e o PLA é, também, satisfatório ${ }^{3,4}$. Estas informações foram compiladas de bases de dados como a Web of Science (http://www.isiknowledge.com).

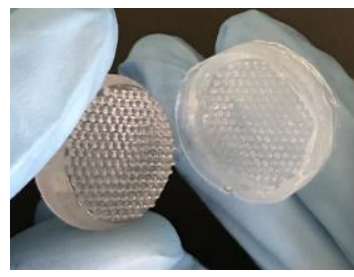

Figura 2. Moldes obtidos no CT Renato Archer. Moldes de Veroclear e agarose, à esquerda e direita, respectivamente

\section{Conclusões}

Os micromoldes devem apresentar cavidades na ordem de $400 \mu \mathrm{m}$, sendo constituídos de resinas ou polímeros não adesivos. Os mais adequados para macromoldes são híbridos de polímeros sintéticos e naturais. Sugerese que as geometrias das cavidades não influenciaram no tecido cartilaginoso obtido, sendo ainda pouco exploradas.

\section{Agradecimentos}

Ao PIBITI/CNPq, pela bolsa concedida.

\footnotetext{
${ }_{1}^{1}$ Dernowsek,J. A. et al. Congresso Latino-americano de órgãos artificais e biomateriais, 2016.

2 Napolitano, A. P. et al. BioTechniques, 2007, 43, 4, 494-500.

${ }^{3}$ Izadifar, J. et al, TISSUE ENGINEERING: Part C, 2016, 22, 3, 173- 188.

${ }^{4}$ Lee, S. et al. Polymers, 2017, 9,.348.
} 